\title{
The Influence of Leadership and Motivation on Lecturer Performance
}

\author{
Dedi Mulyadi \\ Universitas Buana Perjuangan Karawang, Indonesia \\ Email: dedi.mulyadi@ubpkarawang.ac.id
}

\begin{abstract}
:
This research was conducted to determine the effect leadership and motivation for the performance of lecturers at the faculty of Islamic religion at the University of Singaperbangsa Karawang, the object of research is all lecturers at the Faculty of Islamic Religion, Singapore University with a total of 34, the data collection technique uses a questionnaire. The results showed that the relationship between the independent variables, namely between X1 and X2, showed a correlation of 0.876 , this shows that leadership and motivation at the Faculty of Islamic Religion, Singapore University have a strong relationship, meaning that leadership can encourage motivation. $v$ Partial effect between leadership variables on performance amounting to 0.253. with the results of hypothesis testing, the level of significance is $0.012<a(0.05)$, which means that there is a significant influence between leadership and performance. The partial effect of the motivation variable on performance is 0.737 with the results of testing the hypothesis with a significance level of $0.00<a(0.05)$, which means that there is a significant influence between leadership and performance. The joint influence between leadership and motivation variables on performance is shown by the direct influence and indirect influence between leadership and performance by $22.7 \%$, while between motivation and performance is $70.6 \%$. So the overall leadership and motivation variables for performance are $93.3 \%((R Y X)$ 2). The joint influence between leadership and motivation variables on performance is shown by the direct influence and indirect influence between leadership and performance by $22.7 \%$, while between motivation and performance is $70.6 \%$. So the overall leadership and motivation variables for performance are $93.3 \%((R Y X) 2)$. The joint influence between leadership and motivation variables on performance is shown by the direct influence and indirect influence between leadership and performance by $22.7 \%$, while between motivation and performance is $70.6 \%$. So the overall leadership and motivation variables for performance are $93.3 \%((R Y X) 2)$.
\end{abstract}

\section{Keywords:}

leadership; motivation; lecturer performance

\section{Introduction}

Tri Dharma Perguruan Tinggi requires a lecturer to carry out educational and teaching activities, research, and community service. The field of education and teaching is intended to produce educated humans who have knowledge, abilities and attitudes, which means that through educational and teaching activities it is hoped that it can produce graduates or scholars who are knowledgeable, have noble character and have skills (Ujang, 2011). For this reason, in learning activities, a lecturer is required to master various technical and nontechnical abilities starting from designing, implementing to evaluating teaching and learning activities (Jufrizen, 2020).

In the field of research, universities are expected to produce new theories, concepts and methodologies as well as new models and information that can enrich science, technology and culture (Abbas, 2008). For this reason, lecturers are expected to be able to generate ideas, 
concepts and ideas that are expressed either through research activities, making textbooks, writing articles and other scientific works. The birth of various kinds of research works and other written works is an indicator of qualified lecturers who have high performance.

In the field of community service, it is hoped that the existence of higher education institutions can contribute thoughts and energy to the community in order to achieve the progress of the nation (Christianingsih, 2011). Optimizing the process and aspects of human resource management lecturers have an important position in shaping the quality of graduates and the quality of the institution in general (Cahyono, 2012). This position is reinforced by the fact that lecturers have high authority in the academic process as stated in the Teacher and Lecturer Law Number 14 of 2005, that lecturers are professional educators and scientists with the main task of transforming, developing, and disseminating science, technology and art. through education, research, and community service (Ikhsan, 2016).

Therefore, it is hoped that all lecturers are required to be active, creative, innovative and productive in order to prepare students to become members of society who have academic and professional abilities in their fields to apply, develop and disseminate science, technology and art. Furthermore, the quality of college graduates is also determined by the competence of lecturers in the implementation of education, research and community service.

Based on conceptabove, the lecturer performance can be interpreted as all activities carried out by the lecturer related to the duties and functions of the lecturer in educating the human resources of higher education graduates, including the performance of lecturers at the Faculty of Islamic Education, Singapore University, Karawang. Based on observations made on the performance of lecturers at the Faculty of Islamic Education at the University of Singaperbangsa Karawang, it was found that some lecturers teach without making teaching programs, the use of teaching time in lectures is still not optimal, and the number of lecturers who produce scientific works both through research and thinking is still low.

In most cases, the performance of an employee will arise due to the influence of an effective leader, so that leadership effectiveness will show how to motivate employees effectively. According to Wahjosumidjo (2001: 37) a successful leader must have a certain set of talents, including physical strength and nervous system, appreciation of the direction of organizational goals, enthusiasm, hospitality, integrity, technical expertise, decision-making ability, intelligence, teaching skills. , personality, social relationships, health and have a strong desire.

Reliable leadership is an absolute requirement for an organization including universities that require a high level of coordination (Noor, 2020). Leadership is the art and skill of a person to influence others, so that they like and want to work so that goals and desires can be carried out effectively and efficiently. Leaders have an important role in managing the human resources they dream of so that the expected goals can be realized (Prawira, 2018). Leader have responsibility both physically and spiritually for the success of the work activities of those they lead.

A leader is expected to be able to provide direction to achieve the goals of National Education because lecturers have the main task of transforming, developing, and disseminating science, technology, and arts through education, research, and community service. So that lecturers can carry out their duties in achieving the goals of national education, it must be supported by a good work environment. The leadership that took place at the Faculty of Islamic Education, Singaperbangsa Karawang University is currently considered less 
supportive of lecturer performance. From preliminary studies and observations of lecturers at the Faculty of Islamic Education, Singaperbangsa Karawang University, it was found that faculty leaders paid less attention to lecturer performance.

Apart from being influenced by the leadership style of the dean, lecturer performance is also greatly influenced by work motivation. Siagian in Sutrisno (2009), states that motive is a psychological state that encourages, activates or mobilizes and that motive directs and channels one's behavior, attitudes and actions which are always associated with the achievement of both organizational goals and personal goals of each member of the organization. . Meanwhile, Hasibuan (2000) states that motivation is the provision of a driving force that creates a person's excitement in order they are willing to cooperate, work effectively and are integrated with all their efforts to achieve satisfaction.

So motivation questions how to direct the power and potential of his subordinates, so that they are willing to work together productively, succeed in achieving and realizing predetermined goals (Pangaribuan, 2017). If the work motivation of the lecturers is low, the teaching performance of the lecturers is also low, this can be seen from the enthusiasm of the lecturers in providing learning. Motivation is a series of attitudes and values that influence individuals to achieve specific things in accordance with individual goals.

These attitudes and values are invisible which provide the strength to encourage individuals to behave in achieving their goals. Based on observations and preliminary studies conducted on faculty leaders (deans) and students, There are still lecturers who teach not as expected, there are lecturers who only provide training without any teaching and learning process, and lecturers arrive not on time. Departing from the background of the problem above, the researcher took the title "The Influence of Leadership and Motivation on the Performance of Islamic Faculty Lecturers Singaperbangsa Karawang University ".

\section{Research Methods}

The method used in this research isdescriptive and verification methods. Descriptive method is a method in examining the status of human groups of an object, a set of conditions, a system of thought or a class of events in the present. According to Travers in Husein Umar (2009: 22) this method aims to describe the nature of something that was taking place at the time the research was carried out and examine the causes of a particular symptom. Verification method is used to determine the relationship between variables through hypothesis testing. The descriptive method in this research includes descriptive research. Correlation research according to Consuelo in Husein Umar (2009: 25) is a research that designed to determine the level of the relationship of the independent variables to the dependent variable and the magnitude of the direction of the relationship that occurs. The target population in this study were all lecturers at the Faculty of Islamic Studies, Singapore University with a total of 34 people, not including the leaders (deans and heads of study programs).

While the determination of the sample in this study using a census / saturated sample, namely the sampling technique when all members of the population are used as samples (Sugiono, 2009). The data collection technique used in this study was a questionnaire. The data collection technique used in this study was a questionnaire. The quality of data collection in research using quantitative methods is determined by the data collection instrument. The instrument is said to have quality and can be accounted for when its validity and reliability have been tested (Usman and Purnomo, 2003). The instrument that was tested for validity and reliability in this study was a questionnaire that was calculated using SPSS 16 for Windows software. 


\section{Results and Discussion}

Variable data collected through questionnaires in this study are in the form of ordinal data, while to analyze with path analysis, data with at least an interval scale is required. Therefore, the data were increased to interval data with the method of successful interval (MSI). The complete transformation results are as follows:

\subsection{Analysis of the Influence of Leadership and Motivation on Lecturer Performance Magnitude of the Relationship between Independent Variables}

In path analysis, the relationship between variables- independent variables that have a meaningful relationship, can be calculated the amount of direct effect or indirect effect live. The indirect effect is the product of the path coefficient and its correlation coefficient. Therefore, the respective correlation coefficient between the independent variables is calculated first. For more details, the relationship between the two independent variables can be explained in the image below:

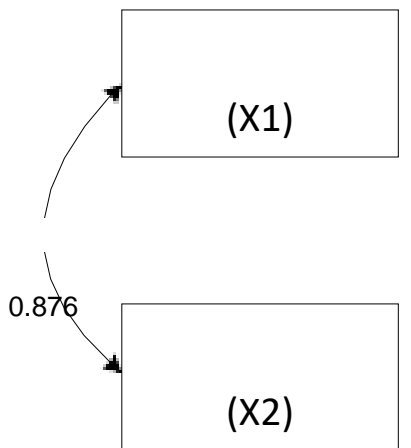

Figure 1. The relationship between the independent Variables

From the analysis, it was found that the correlation coefficient between the independent variables, namely the relationship between the leadership variable (X1) and motivation (X2), obtained a value of 0.876 which means that it has a very strong and unidirectional level of relationship because the value is positive.

\subsection{Path Analysis}

\section{Partial Influence of $\mathbf{X}$ on Variable $\mathbf{Y}$}

Direct effect of variable X1, namely leadership towards variable $\mathrm{Y}$, namely lecturer performance can be described as shown in Figure 2 below:

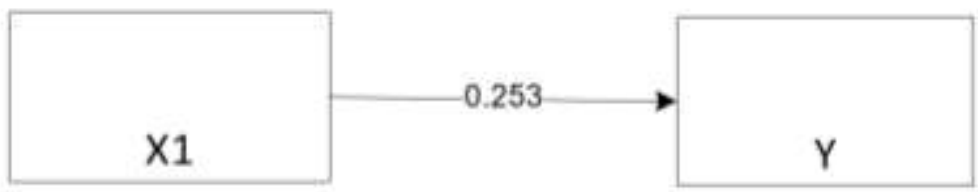

Figure 2. Partial Effect of Independent Variable X1 on Bound Variable Y

The equation of the partial effect of variable $\mathrm{X} 1$ on variable $\mathrm{Y}$ is: $\mathrm{Y}=0.253 \mathrm{X} 1$

For the direct effect of variable $\mathrm{X} 2$, namely motivation to variable $\mathrm{Y}$, namely lecturer performance, it can be described as shown in Figure 3 below:

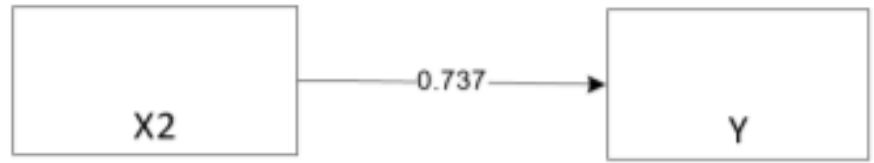

Figure 3. Partial Effect of Independent Variable X2 on Bound Variable Y 
The equation of the partial effect of variable $\mathrm{X} 2$ on variable $\mathrm{Y}$ is: $\mathrm{Y}=0.737 \mathrm{X} 2$

For the direct effect of variable $\mathrm{X} 1$ and $\mathrm{X} 2$ for the variable $\mathrm{Y}$ can be described as shown in Figure 4 below:

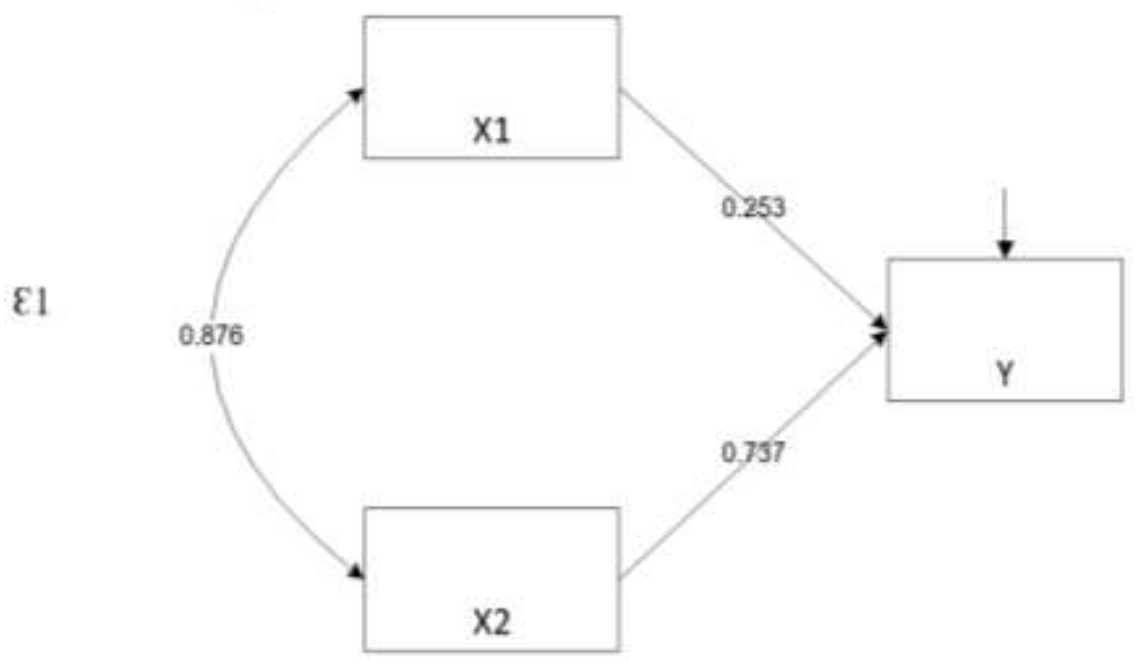

Figure 4. Direct Effect of Variables X1 and X2 on Variable $Y$

Influence model direct variables $\mathrm{X} 1$ and $\mathrm{X} 2$ to variable $\mathrm{Y}$, namely: $\mathrm{Y}=0.253 \mathrm{X} 1+$ $0.737 \mathrm{X} 2+\varepsilon 1$

From the above equation it can be interpreted that:

1. There is an associative relationship between leadership and lecturer performance, the amount is 0.253 (@YX1).

2. There is an associative relationship between motivation and lecturer performance, the amount is 0.737 (@YX2).

The Simultaneous Effect of Variable X on Variable Y.

The direct and indirect effects simultaneously of variables $\mathrm{X} 1$ and $\mathrm{X} 2$ on $\mathrm{Y}$ are as follows:

1. Magnitude of Direct Influence

a. The direct effect of variable X1 on Y is $6.4 \%(\varrho 2 \mathrm{yx} 1)$

b. The direct effect of variable X2 on Y is $54.3 \%(\varrho 2 \mathrm{yx} 2)$

2. Magnitude of Indirect Effect

a. The total indirect effect of variable $\mathrm{X} 1$ on $\mathrm{Y}$ is $16.3 \%$.

b. The total indirect effect of variable $\mathrm{X} 2$ on $\mathrm{Y}$ is $16.3 \%$.

The total effect of the variablesX1, $\mathrm{X} 2$ on $\mathrm{Y}$ is stated by the magnitude of the coefficient of determination (RYX) 2 of $93.3 \%$, while the influence of other variables outside the model is $6.7 \%$. For more details, it can be seen in the table below:

Table 1. Direct and Indirect Effects of Variables X and Y

\begin{tabular}{|c|c|c|c|c|c|}
\hline \multirow{2}{*}{ Variable } & $\begin{array}{c}\text { Influence Jump } \\
\text { to Y }\end{array}$ & \begin{tabular}{l} 
Influence No. Live \\
\cline { 3 - 4 }
\end{tabular} & $\begin{array}{c}\text { Total Indirect } \\
\text { Effect }\end{array}$ & $\begin{array}{c}\text { Total } \\
\text { Influence }\end{array}$ \\
\hline $\mathbf{X 1}$ & 0.064 & - & 0.163 & 0.163 & $\mathbf{0 . 2 2 7}$ \\
\hline $\mathbf{X} 2$ & 0.543 & 0.163 & - & 0.163 & $\mathbf{0 . 7 0 6}$ \\
\hline \multicolumn{5}{|r|}{ Total Influence } \\
\hline
\end{tabular}

Source: processed products 


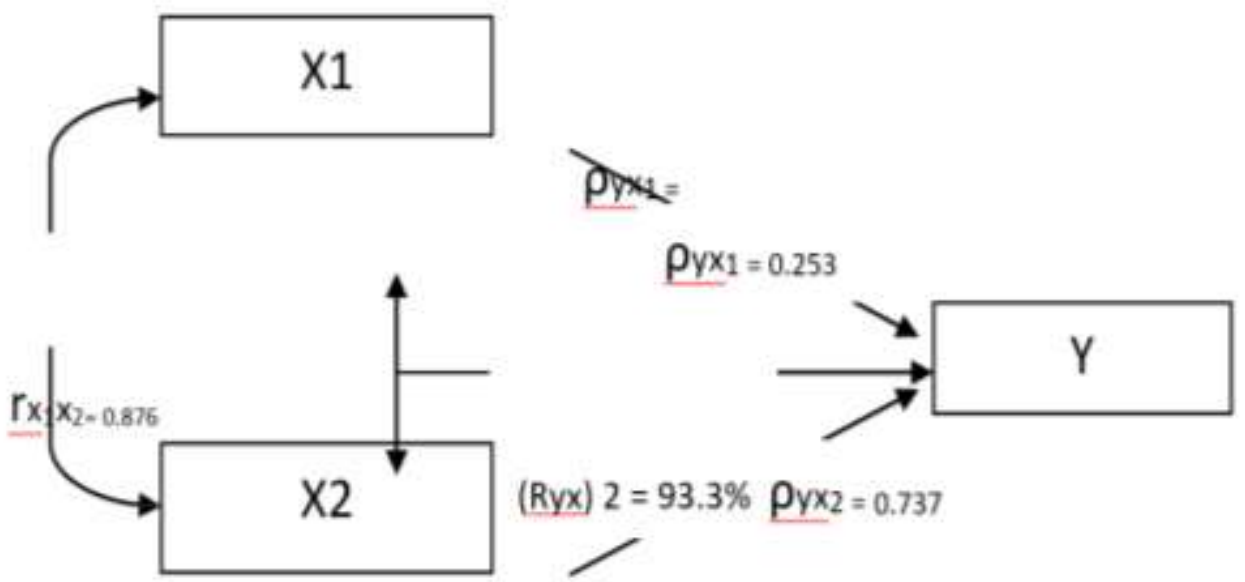

Figure 5. The simultaneous effect of Variables X1 and X2 on Variable $Y$

\subsection{Testing the Influence Hypothesis Partially for Variable $\mathrm{X} 1$ and $\mathrm{X} 2$ against $\mathrm{Y}$}

The results of statistical tests on the effect of the independent variables (X1, X2) on the dependent variable $(\mathrm{Y})$ using the hypothesis:

Ho: $\varrho \mathrm{YXi}=0 \rightarrow$ there is no partial influence of the independent variable $(\mathrm{Xi})$ on the dependent variable $Y$.

H1: $\varrho Y X i \neq 0 \rightarrow$ there is a partial effect of the independent variable $(\mathrm{Xi})$ on the dependent variable $\mathrm{Y}$.

With the test criteria: Reject Ho if Sig. $<\alpha$ or t count $>$ t table

Table 2. Result of partial path analysis

\begin{tabular}{|l|l|l|l|}
\hline Structural & Sig. & $\boldsymbol{\alpha}$ & Conclusion \\
\hline$\varrho Y X 1$ & 0.012 & 0.05 & Ho was rejected, there is a significant effect \\
\cline { 1 - 1 } \cline { 4 - 4 } 2 & 0,000 & & Ho was rejected, there is a significant effect \\
\hline
\end{tabular}

Source: Results of statistical calculations (attached)

From the table above, the following results are obtained:

a. For the partial effect of X1 on Y, the value of Sig. $(0.012)<\alpha(0.05)$ then Ho is rejected. Thus it can be concluded that leadership partially has a significant effect on lecturer performance.

b. For the partial effect of X2 on Y, the Sig. $(0,000)<\alpha(0.05)$ then Ho is rejected. Thus it can be concluded that motivation partially has a significant effect on lecturer performance.

\subsection{Testing the Simultaneous Influence of Variable $\mathrm{X} 1$ and $\mathrm{X} 2$ against $\mathrm{Y}$}

The results of the statistical test of the effect of X1 and X2 simultaneously on Y using the following hypothesis:

Ho: $\varrho Y X 1=\varrho Y X 2=0 \rightarrow$ There is no influence at the same time from the independent variable $\mathrm{X}$ to the dependent variable $\mathrm{Y}$

H1: @YX1 $\neq \varrho Y X 2 \neq 0 \rightarrow$ There is influence in a manner concurrent of variables independent X on the dependent variable Y. With the test criteria: Reject Ho if Sig. $<\alpha$ or F count> F table. 
Table 3. The Simultaneous Influence of Variable X on Y

\begin{tabular}{|l|l|l|l|}
\hline Model & Sig. & $\boldsymbol{\alpha}$ & Conclusion \\
\hline $\mathrm{QYX}$ & 0,000 & 0.05 & Ho was rejected, there is a significant effect \\
\hline
\end{tabular}

Source: Results of statistical calculations (attached)

From the table above, it can be seen that the Sig. amounting to 0,000 which is smaller than $\alpha(0.05)$. Thus Ho is rejected, so it can be concluded that leadership and motivation simultaneously have a significant effect on lecturer performance.

\section{Conclusion}

Based on the results of the analysis of leadership and motivation variables on performance, in a study conducted at the Islamic Faculty of Singapore, Singaperbangsa Karawang University in 2019 with 34 respondents, all lecturers, it can be concluded that:

1. Leadership with the dimensions of communication, motivation, work discipline, work productivity and decision-making strategies has an average score of 118.62 in the range 115.6 - 142.7, this shows that the respondents agreed with the leadership at the Islamic Faculty of Singapore University. Karawang

2. Motivation with the dimensions of hard work, efforts to progress, persistence and task orientation has an average score of 108.09 in the range $88.4-115.5$, this shows that respondents quite agree with the motivation that occurs in the Islamic Faculty of Singapore University. Karawang Performance with the dimensions of performance in education and teaching, performance in research and performance in community service has an average score of 118.67 in the range 115.6 - 142.7, this shows that the respondents agreed with the performance of lecturers at the Faculty of Islam, Singaperbangsa Karawang University

3. Leadership partially has a positive and significant effect on performance by $22.7 \%$ with a significance level of $0.012<\alpha(0.05)$.

4. Motivation has a positive and significant effect on performance by $70.6 \%$ with a significance level of $0.00<\alpha(0.05)$

5. Leadership and motivation together have a positive and significant effect on performance by $93.3 \%$ with a significance level of $0.00<\alpha(0.05)$.

Sugestion from the conclusions described above, suggestions are given as following:

1. Leadership at the Islamic Faculty of Religion is still on a fairly agreeable scale, which reflects that the dimensions of the function of communication, motivation, work discipline and decision-making strategies are still not optimal, it is hoped that the leadership function must be improved.

2. Lecturer motivation in terms of working hard, efforts to progress, persistence and average assignment orientation is still on a sufficient scale, therefore for the institutions to provide motivation by holding regular meetings to discuss things that can encourage lecturer motivation in carrying out their duties and responsibilities responsibility, carry out seminars in an effort to increase knowledge, encourage lecturers to continue with higher education and provide direction on duties and responsibilities. 


\section{References}

Abbas, S. (2008). Manajemen perguruan tinggi. Kencana.

Cahyono, A. (2012). Analisa pengaruh kepemimpinan, motivasi dan budaya organisasi terhadap kinerja dosen dan karyawan di Universitas Pawyatan Daha Kediri. Jurnal Ilmu Manajemen, Revitalisasi, 1(1), 283-298.

Christianingsih, E. (2011). Manajemen Mutu Perguruan Tinggi (Studi tentang Kpemimpinan Visioner dan Kinerja Dosen terhadap Mutu Perguruan Tinggi Swasta di Kota Bandung). Manajerial: Jurnal Manajemen dan Sistem Informasi, 10(1), 31-41.

Ikhsan, A. (2016). Analisis Pengaruh Budaya Organisasi dan Kepuasan Kerja Terhadap Kinerja Karyawan Non Dosen Pada Universitas Mercu Buana Jakarta. Jurnal Ilmiah Manajemen Dan Bisnis Mercu Buana, 2(1), 97055.

Jufrizen, J., Farisi, S., Azhar, M. E., \& Daulay, R. (2020). Model Empiris Organizational Citizenship Behavior dan Kinerja Dosen Perguruan Tinggi Swasta di Medan. EKUITAS (Jurnal Ekonomi dan Keuangan), 4(2), 145-165.

Noor, W., \& Juhji, J. (2020). Integrasi Budaya Prestasi pada Fungsi Perencanaan Pembinaan Mutu Dosen. Al-Tanzim: Jurnal Manajemen Pendidikan Islam, 4(1), 1-12.

Pangaribuan, W. (2017). Pengaruh Budaya Organisasi, Komitmen Organisasi, Komunikasi Interpersonal, dan Efektivitas Sistem Pengendalian Manajemen Kinerja terhadap Kinerja Dosen (Doctoral dissertation, UNIMED).

Prawira, W., \& Yogie, R. (2018). Marketing Communication On The Environment Protection On Annual Haze Smoke In Riau Province (No. 7208579). International Institute of Social and Economic Sciences.

Siagian, SondangP. (2002). Organizational Apparatus Ability and Administrative Behavior. Jakarta GA

Sugiono. (2006). Administrative Research Methods. Alfabeta, Bandung.

Sutrisno. 2009. Human Resource Management. Kencana Prenada Media Group, Jakarta.

Ujang Charda, S. (2011). Peranan Pendidikan Tinggi Hukum Dalam Memenuhi Tuntutan Dunia Kerja. Jurnal Wawasan Hukum, 24(01).

Umar, Husein. 2005. Human Resource Research in Organizations. PT. Gramedia Pustaka Utama, Jakarta.

Usman, H. and R. Purnomo. SA 2003. Introduction to Statistics. Balai Aksara, Jakarta.

Wahjosumidjo. (2001). Leadership Head School Review theoretical And The problem. Raja Grafindo Persada. Jakarta. 